\title{
The Impact of the Fiscal Policy on Income and the Consumption of the Poor Households in Morocco: An Analysis with a Computable General Equilibrium Model (CGEM)
}

\author{
El Moussaoui Mohamed ${ }^{1} \&$ Mohamed Karim ${ }^{1}$ \\ ${ }^{1}$ EREMEFP, University of Mohammed V, Rabat, Morocco \\ Correspondence: Mohamed Karim, University of Mohammed V, Rabat, Morocco. Tel: 212-6618-3260. E-mail: \\ xmedkarimx@gmail.com
}

Received: January 30, 2017

Accepted: February 28, 2017

Online Published: March 10, 2017

doi:10.5539/ijef.v9n4p79

URL: https://doi.org/10.5539/ijef.v9n4p79

\begin{abstract}
This article examines the effects of the fiscal policy on income and the consumption of the poor households in urban and rural areas. The evaluation of this impact is carried out by the use of a real and static Computable General Equilibrium Model (CGEM) in open economy and with government. The Social Accounting Matrix of the year 2013 is used for the supposed simulations.

The results obtained show clearly that $50 \%$ direct tax reduction in income for the urban poor households and $100 \%$ for the rural ones make it possible to increase significantly the disposable income of these households as well as improving their consumption. On the other hand, the other policies such as exempting the agricultural and food commodities from the indirect tax, combined with $20 \%$ increase in this tax for the industrial products and the private services, or the exemption of the agricultural and food products from the customs duties, do not have a positive effect on the income and the consumption of the poor households.
\end{abstract}

Keywords: fiscal policy, poverty, computable general equilibrium model

\section{Introduction}

Recently, the Moroccan public govenment have set up a certain number of programms and projects with the objective of eradicating the poverty and introducing social and spatial equity. They mainly target the implementation of the National Initiative of Human development (INDH), along with launching great structuring projects, reforming public education, improving health care access conditions as well as promoting employment. The evaluation of the effects of these policies on poverty is a controversial issue among economists nowadays. Additionally, a certain number of studies have been carried out to estimate and measure the impact of various economic policies on poverty and income distribution in Morocco.

The main aim of this work is to study the impact of the fiscal policy on the income and the poor household consumption in Morocco. The supposed simulations are made within the framework of a Computable General Equilibrium Model (CGEM) in which the labor factor is disaggregated into three categories according to the qualification level (unqualified workers, moderately qualified workers and highly qualified workers) and the household is disaggregated into four categories according to the place of living (urban or rural), and the income level (the poor or non-poor). The model is calibrated by using the most recent data available, such as the Social Accounting matrix of Morocco of 2013, that was published by the HCP (High Commission for Planning) in June 2016; and the the results of ENNVM of 2007 (National Survey on Linving Standards of the Households).

The first section of this work discusses the various characteristics of poverty in Morocco, and it also presents the principal public policies implemented by the Moroccan public authorities to reduce poverty. The second section explains the theoretical framework and the description of the model. The third presents the three simulated scenarios of the fiscal policy and describes the results obtained of a comparative analysis carried out with reference to the source data. This analysis focuses primarily on the disposable income and the consumption of the urban and rural poor households. 


\section{Morocco's Experience in Fight Against Poverty}

\subsection{Characteristics of Poverty in Morocco}

\subsubsection{Absolute Poverty}

The HCP defines absolute poverty line as the food poverty line raised by the cost of non-food acquisitions. The food poverty line corresponds to the cost of a basket of food commidities and services guaranteeing the necessary minimum amount of calories. This minimum is equivalent, according to the standard recommended by FAO and WHO, to 1984 kilogram calories per day and per person. It can be obtained by the households which can satisfy their food needs only if they devote the sum of their whole budget to this type of acquisitions. The ENNVM 2007 results show that food poverty line amount passed from 1752Dhs in 2001 to 2012Dhs in 2007 with an increase of 14,9\%. The absolute poverty line also knew an important reduction between 2001 and 2007, passing from $6,7 \%$ to $3,9 \%$ at the national level. In the rural areas, this fall is highly noticeable (from $12,3 \%$ to $7,2 \%$ ) compared to the urban ones (from $2,3 \%$ to $4,8 \%$ ).

Table 1. Food poverty line in DH currency

\begin{tabular}{lcccc}
\hline Food poverty line (in DH) & 1985 & 1998 & 2001 & 2007 \\
\hline Urban & 961 & 1756 & 1752 & 2012 \\
Rural & 961 & 1731 & 1752 & 2012 \\
\hline
\end{tabular}

Sources: HCP: ENNVM 1998/1999 et 2006/2007, ENCDM: 1984/1985 et 2000/2001, Direction de la Statistique, Observatoire des Conditions de Vie des Ménages.

Table 2. Absolute poverty indicators (\%)

\begin{tabular}{lcccc}
\hline Poverty line rate & 1985 & 1998 & 2001 & 2007 \\
\hline Both rural and urban & 12.5 & 7.8 & 6.7 & 3.9 \\
Urban & 6.8 & 2.5 & 2.3 & 1.3 \\
Rural & 16.8 & 14.1 & 12.3 & 7.2 \\
\hline
\end{tabular}

Sources: HCP: ENNVM 1998/1999 et 2006/2007, ENCDM: 1984/1985 et 2000/2001, Direction de la Statistique, Observatoire des Conditions de Vie des Ménages.

\subsubsection{Relative Poverty}

There are several methods used to measure relative poverty. The HCP adopts the approach used by the World Bank which considers relative poverty as the combination of food poverty line and non-food allowance. This allowance corresponds to the cost of non-food acquisitions perceived by the households which actually meet the minimum basic food needs. Then, according to this approach, the rate of relative poverty in Morocco decreased from $15,3 \%$ to $9 \%$ between 2001 and 2007. In rural areas, this fall reached 5,6\%.

Table 3. Relative poverty indicators (\%)

\begin{tabular}{lccccc}
\hline Relative poverty rate & 1985 & 1998 & 2001 & 2007 \\
\hline Both urban and rural & 21.0 & & 16.2 & 15.3 & 9.0 \\
Urban & 13.3 & 9.5 & 7.6 & 4.8 \\
Rural & 26.9 & 24.1 & 25.1 & 14.5 \\
\hline
\end{tabular}

Sources: HCP: ENNVM 1998/1999 et 2006/2007, ENCDM: 1984/1985 et 2000/2001, Direction de la Statistique, Observatoire des Conditions de Vie des Ménages.

The average annual expenditure of households (DAMM) is another indicator used to study the living standard of the population and measure poverty. According to the results of the ENNVM of 2007, the DAMM in Morocco is $57.925 \mathrm{DH}$. It is estimated at $66.724 \mathrm{DH}$ per day in the urban areas, corresponding to $5.560 \mathrm{DH}$ per month, while reaching 43.334 DH per day in the rural areas, equaling 3.611 DH per month.

Between 1998 and 2007, the DAMM recorded an increase of 25\% at the national level. It was an average annual increase of about $2,7 \%$. This development was more important in the rural areas (nearly $34 \%$ ) than in the urban ones $(17,5 \%)$. 
Table 4. The development of the household average annual expenditures according to the place of living (current DH value)

\begin{tabular}{cccc}
\hline Period & Urban & Rural & Both \\
\hline 1985 & 26667 & 16824 & 21475 \\
1991 & 48192 & 28584 & 38600 \\
1998 & 56781 & 32372 & 46339 \\
2001 & 58900 & 33994 & 49333 \\
2007 & 66724 & 43334 & 57925 \\
\hline
\end{tabular}

Sources: HCP: ENNVM 1998/1999 et 2006/2007, ENCDM: 1984/1985 et 2000/2001, Direction de la Statistique, Observatoire des Conditions de Vie des Ménages.

According to the statistics mentioned above, we can conclude that poverty in Morocco is a rural phenomenon. During the last two decades, a shrinking tendency of the phenomenon emerged. The development observed as well as the current state can be justified by the general progress made in the national macroeconomic domain and the effects of the public policies.

\subsubsection{Multidimensional Poverty and Development Indicators}

Based on the data of the report on human development issued in 2015, the human development index (HDI) in Morocco passed from 0,399 in 1980 to 0,628 in 2014, which makes it ranked number 126 in the world. It should be noted that this index, calculated for Morocco, is strongly influenced by the mean years of schooling which does not exceed 4,4 years, whereas the mean on a world level is 7,9 years. This low level can be explained partly by the rate of illiteracy which is still high, particularly in the rural areas.

It arises from the same report that the index of multidimensional poverty (IMP) for Morocco, based on the statistics of 2011, doesn't exceed 0,069. This index which captures the multiple deprivations that people face in their education, health and living standards, indicates that more than $15,6 \%$ of the Moroccan population live in multidimensional poverty.

\subsection{The Public Policy for Poverty Eradication}

To face the social deficit and reduce poverty, Morocco has lately considered qualifying the human capital as a priority of the public action. This orientation has been confirmed, on the one hand, by taking a certain number of initiatives and actions aiming mainly at the reduction of the social and spatial disparities, and on the other hand, granting the social sectors about half of the National General Budget expenditures of the finance law. Thus, several sectors have been targeted such as providing assistance to the farmer, reforming the educational system, improving the sanitary services, reinforcing the offers of decent housing, promoting job opportunities for the young people, and reinforcing social cohesion.

\subsubsection{Plan «Maroc Vert»}

In April 2008, Morocco launched a great project whose main aim was to give the agricultural sector the priority in order to boost socio-economic development in Morocco. The first of its implementations concerns the development of a modern agriculture which has a high value added, and that is characterized by a production matching the international standards. As for the second, it is interested in the small agriculture by developing an interdependent approach directed towards the fight against poverty and the diversification of the revenue resources for the most vulnerable rural populations.

\subsubsection{The National Initiative for Human Development (INDH)}

It is a program launched by his Majesty the King Mohammed the $6^{\text {th }}$ on May 18th, 2005. Firstly, it targets the excluded and the poor populations. The stated objectives to fulfill on the short and medium terms are to reduce poverty, vulnerability, precariousness and social exclusion. On the long run, they stimulate a durable dynamic in favor of human development and the population well-being as well as improving the HDI (Human development index).

Eleven years after the INDH was launched, the daily life of a great number Moroccans has been changing dramatically. The implementation of the four INDH programmes over the period of 2005-2015 has contributed in the achievement of 42475 projects including 8300 income generating activities, and 10271 actions for a total investment of 32,4 billion Dirhams. The total number of the benefit recipients of these projects is about 10 million people, $50 \%$ of which live in rural areas.

\subsubsection{Educational Reform and the Fight Against Illiteracy}

In spite of the successive and multiple reforms carried out by Morocco to improve the quality of education, 
several evaluation reports of these reforms have all confirmed that the results are not always as satisfactory as aspired. Thus, to face these dysfunctions, a new strategic vision of the educational reform has been established by the Superior Council of Education, Training and the Scientific Research for the period of 2015-2030. Several objectives were determined, the most important of which are a schooling characterised by equity and equality, and an improvement of the quality of teaching and training.

With regard to illiteracy, Morocco has not ceased, throughout the last decade, intensifying its efforts to gain the challenge of illiteracy eradication. In fact, the creation of the National Agency of Fight against Illiteracy reflects the determination of the public authorities to put their commitment forward in favor of illiteracy eradication. The efforts made in this context brought the illiteracy rate back to less than $32 \%$ in 2014 compared to $43 \%$ in 2004 .

\subsubsection{Employment Promotion}

One of the priorities of Morocco's social program is promoting employment. The Moroccan government has taken several actions aiming mainly at consolidating active employment measures, encouraging self-employment, and improving the youth qualifications. Within this framework, several programs have been recently launched namely IDMAJ program- TAEHIL program - AUTO-EMPLOI program - TAHFIZ program.

\subsubsection{Health Care Access Improvement}

The improvement of health care levels constitutes an essential component and a priority for the social development policy adopted by Morocco. It entails improving health care of the distant populations wedged in rural areas by providing services essential to improving health care access for people with handicaps and the elderly. Within this framework, a new program called RAMED- the system of medical help for the destitute people, was set up targeting people in poor situations. This system makes it possible for the benefit recipients to get access to quality and secured health care at the right time regardless of their ability to pay, in addition to providing them with drugs and medicinal products. In the same line, several efforts have been made as regards the extension of basic medical cover to the benefit of professional students, self-employed and unsalaried workers in small business ventures along with helping the parents of the insured ones benefit from the obligatory health insurance.

\subsubsection{Other policies}

- Improvement of the housing conditions: The public policies regarding housing always aim at reducing unhealthy accommodations and enhancing the lifestyle of the vulnerable households.

- The Global Rural Electrification program (PERG): This program has allowed nearly 2093881 homes of about 12,5 million inhabitants to have access to the electricity services. Thus, the rate of rural electrification has reached $99,2 \%$, which is much more than $18 \%$ achieved in 1995. The cost of the investment was estimated at 22,69 billion Dirhams.

- The Drinking Water Group Supply Program of the Rural Populations (PAGER) has the objective of providing drinking water to 31000 localities sheltering 11 million inhabitants. This program whose cost is estimated at nearly 10 billion Dirhams has made it possible to increase the drinking water access rate to $95 \%$ in rural areas.

- The national plan of the Rural Roads (PNRR). This program allowed the rural population a bigger access to other localities which reached $78 \%$ in 2015.

\section{Literature Review}

During the last three decades, the developing countries faced major macroeconomic shocks. They were due mainly to commercial liberalization, the implementation of structural adjustment programs and the world price fluctuations of raw materials. The repercussions of these policies had negative impact on the social and economic life of these countries, particularly on poverty and inequality.

To measure the impact of the various economic reforms to be implemented in the developing countries, new models largely used in the developed countries, are introduced. These models are called the Computable General Equilibrium Models (MEGC) which were developed thanks to advances in technological tools and the increasing availability of statistical data.

These MEGC make it possible to describe the links between the macro-economic policies and the micro-economic behaviors. In other words, they make it possible to illustrate the transmission systems of the effects of the economic shocks, and explain the impact of the public policy on incomes and the economic agents consumption, especially on the households. Within this framework, several studies were carried out to examine the reactions and the changes in the behavior of the agents in the short and long terms following the introduction of various policies namely the commercial liberalization, the budget policy, increase in public investments... etc. 
Thus, the first economists having studied the impact of the economic reforms in the developing countries, by the use of the MEGC, were interested in analyzing the problems related to poverty and the income distribution.

The first works having used these models in a developing country were those of Adelman and Robinson (1978) in South Korea, Taylor and Lysy (1979) in Brazil, Dervis, de Mello and Robinson (1982) and Gunning (1983) in Kenya, and Burgundian, Michel and Miqueu (1983) in Venezuela.

In the beginning of 1990, under the aegis of OECD, several works were realized to study the impact of the programmes of structural adjustment on the distribution of income. To examine the distribution of income in Indonesia, Thorbecke (1991) noticed that the program of structural adjustment made it possible to restore balance and to improve the distribution of income. Burgundian, de Mello, and Morrison (1991) examined poverty and the distribution of income during the period of the implementation of the structural adjustment programme in a number of countries including Morocco. The work carried out by Lambert, Schneider and Suwa (1991) in the case of Ivory Coast showed that the reduction of public expenditure by reducing the salaries of the civil servants can lead to inequality reduction. Sahn, Dorosh, and Younger (1997) examined the impact of the trade and the liberalization of the exchange rate on the distribution of income and poverty in countries like Cameron, Gambia, Madagascar and Niger. The results of this work showed that these measurements were as beneficial for the poor households as they were for the rural ones. Bautista and Thomas (1997) also demonstrated, in their study, the positive impact of imports liberalization on poverty in the Philippines. Hans lôfgren (1999) analyzed the impact of the commercial policy on the poor in Morocco. The results illustrated that reducing the protection of the agricultural sector can, on the one hand, increase thel well-being, but on the other hand, it can have negative effects on the vulnerable rural population. Decaluwé, Dumont, and Savard (1999) evaluated the impact of the economic policy shocks on poverty and income distribution by the use of the new approach based on the principle of microsimulations. Very recently, the researchers X. Diao, Doukkali, and Yu (2008) stadied the policy options and their potential effects on Moroccan small farmers. This study emphasizes the close relationship between poverty alleviation and agricultural policies. It shows that combining direct transfers to poor consumers with increased public investment in agriculture to improve agricultural prodictivity is a win-win strategy that the government should consider. A. Touhami with Bocanfusso and Savard (2009) studied the impact of the economic policies on poverty in Morocco. It arises from the results obtained in this study that the sector of tourism in Morocco may contribute in reducing the inequalities at the national level for both the rural and urban populations. In a recent study, Aredo et al. (2012) analyse the effect of trade liberalization on poverty and inequality in Ethiopia. They observe a decline in the overall output in the economy as well as an increase in poverty when applying trade liberalization, although farming agriculture sector benefits from openness. The study also shows an increase in volume of imports, while exports slightly increase. Diagne et al. (2013) find positive effects when applying the Common External Tariff in Senegal. Although rural households show a good performance, reducing poverty, these effects are clearly stronger in urban areas.

\section{Research Methodology}

The model built to analyze the impact of the economic policies on poverty and inequality in Morocco is a real static CGEM in open economy and with government. It is based on model PEP-1-1 (Partnership for Economic Policy) developed by Decaluwé, Lemelin, Robichaud, and Maisonnave (2013).

In this study, the CGE Model with Representative Household (CGE-RH) framework is adopted. This approach is the traditional method which has been widely applied in addressing an impact of policy on income distribution. Poverty analysis is performed by using the variation of income of the RH generated by CGE model with household survey data to perform ex ante poverty comparison. Although, this approach is easier to use because it does not require specific modeling effort, but it can not capture intra-group income distribution change. Then, the distribution of relative income within each RHG is policy-neutral, that is, it is not affected by any change in macroeconomic policy; and the demographic weight of households in each RHG is constant. Hence, this approach essentially focuses on changes in the distribution between RHGs. Empirically, however, analyses of micro data show that changes of within-RHG inequality can be as important as changes of between-RHG inequality in explaining the evolution of overall inequality.

The model includes five branches of activity (Agriculture, constructions, industry, private services and public administration). Two factors of production are distinguished. The factor of labor is divided into three types according to the qualification level (unqualified, moderately qualified and highly qualified workers). The factor of capital is supposed to be specific and fixed by sector. The model specifies 7 agents. There are 4 categories of households, the firms, the government and the rest of the world. The households are disaggregated according to the place of living (Urbain/ Rural) and according to the level of income (the non-poor/ poor). 
The sectoral output of each productive activity combines value added and total intermediate consumption in fixed shares, following a Leontief production function. The aggregate intermediate consumption is made up of various goods and services. It is assumed that intermediate inputs are perfectly complementary, and are combined following a Leontief production function. No substitutions are possible. each industry's value added consists of composite labor and capital, following a constant elasticity of substitution (CES) specification. This labor is understood as a composite factor of the three types of qualifications. These various categories of labor combined following a constant elasticity of substitution (CES) technology, which reflects the imperfect substitutability between different types of labor. The firm chooses its labor composition so as to minimize its labor cost given the relative wage rates. Labor demand of each type derives from the first-order conditions of cost minimization by the representative firm, subject to the CES.

The households incomes come from three sources: labor income, capital income, and transfers received from other agents (other households, firms, government and rest of the world). Each household type receives a fixed share of the earnings of each type of labor. Likewise, total capital income is distributed between agents, including households, in fixed proportions. Finally, transfer income is simply the sum of all transfers received by type households. All the shares are calibrated on the data of the year 2013. The household disposable income is obtained by subtracting direct taxes and household transfers to government which include contributions to the social programs. Finally, the saving rate of each household is a linear function of disposable income.

It is assumed that households have Stone-Geary utility functions (from which derives the Linear Expenditure System). A characteristic of these utility functions is that there is a minimum level of consumption of each commodity (which may be zero for some commodities).

Business income consists, on the one hand, of its share of capital income, and, on the other, of the transfers received from other agents. Deducting business income taxes from total income yields the disposable income of each type of business. Likewise, business savings are the residual that remains after subtracting transfers to other agents from disposable income.

The government draws its income from household and business income taxes, taxes on products and on imports, and taxes on production. Taxes on products and imports consist of indirect taxes on consumption, taxes and duties on imports. In addition to these various forms of fiscal revenue, government receives part of the remuneration of capital and transfers from other agents. Similarly to what has been done with household savings, income taxes are described as a linear function of total income, whether it is for households or for businesses.

The commercial exchanges with the rest of the world (imports and exports) are modeled following a constant elasticity of substitution (CES) technology or following a constant elasticity of transformation (CET) function, with the assumption of the small country for all the products (principle of Armington, 1969). The prices of the imported and exported goods are thus exogenous and fixed. Their equivalents in Dirhams are deduced by taking into account a "nominal foreign exchange rate", as well as the taxes, which are related to the customs duties in particular.

The pricing system naturally depends on the assumptions and the functional forms used in the model. The equilibrium conditions of the model are ensured by the supply and demand equilibrium for the goods and services market and the factors market.

To close the model, the variables fixed as exogenous variables are as follows : the public consumption, the current account balance, the volume of inventory change of each product, the total supply of labor, minimum consumption, nominal foreign exchange rate (numerary of the model) and the international prices in foreign currency of the imported and exported goods (assumption of the small country).

The model stands on the Social Accounting Matrix of Morocco of 2013 realised by the HCP. This data is supplemented by the results of the national survey on the standard of living of the households carried out in 2007 as well as by the social indicators of Morocco in 2012.

\section{Research Findings and Results}

\subsection{Simulated Scenarios}

In order to illustrate the variation of the income levels and housholds consumption particularly for the poor, we retain the three following scenarios:

The first of these simulations (SIM 1) consists of reducing the marginal rate of the income tax of the poor urban households by $50 \%$ and that of the poor rural households by $100 \%$. These reductions are made with reference to their basic level in the SAM of 2013. The national debates about the tax reform held in 2013 recommended 
improving the purchasing power of the most deprived classes by reducing the fiscal cost. So the objective of this simulation is to detect the effect of direct tax reduction (THD) on the total income (YH), the disposable income (YHD) and the household consumption (C).

The second simulation (SIM 2) consists of increasing by $20 \%$ the marginal rate of the indirect tax on the industrial products (IND) and the private services (SER), and to exonerate from this tax the agricultural produce (AGR), the food products (ALIM) and public services (ADM). This simulation seeks to evaluate the effect of the indirect tax imposed on the products on the purchasing power of the households. Thus, the reform of the fiscal policy in Morocco is directed towards reducing the number of tax rates of the value added. Moreover, this reform aims at fixing low tax rates $(0 \%$ or $10 \%)$ for the products basically consumed by the socially poor people and the normal tax rate (20\%) for the other products. For this reason, we combined, in this simulation, the exemptions of the agricultural commodities and food products as well as public services offered by the administration, with a $20 \%$ increase in the marginal tax rate for the industrial products and the private services.

The third simulation (SIM 3) supposes an exemption from customs duties for the agricultural and food products. Morocco is committed, under the terms of a certain number of free trade agreements signed with several of its business partners, to liberalize its foreign trade. This liberalization is generally reflected though reducing the customs duties imposed on the imports, and eliminating non-tariff barriers. However, to protect the agricultural sector and more particularly small farmers, the products of this sector were initially excluded of the provisions of these agreements. Thus, the importation tax imposed on these products remains high (between 25\% and 200\%). Then, to evaluate the effectiveness of this policy, the simulation analyzes the impact of exempting the agricultural and food products from customs duties (TIM) on the purchasing power of the poor households.

\subsection{Description and Analysis of the Results}

In this section, the principal results obtained from the three simulations are presented as follows.

\subsubsection{The Variation of Incomes}

Table 5. Variation of incomes (by \%)

\begin{tabular}{|c|c|c|c|c|c|}
\hline & & Basic level & SIM1 & SIM2 & SIM3 \\
\hline \multicolumn{2}{|c|}{ GDP at a basic price } & 818413 & 0.026 & -0.360 & -0.926 \\
\hline \multicolumn{2}{|c|}{ Government income } & 360310 & -24.212 & -23.799 & -25.897 \\
\hline \multicolumn{2}{|c|}{ Firms income } & 362539 & 0.030 & -0.348 & -1.117 \\
\hline \multirow{4}{*}{$\begin{array}{l}\text { Disposable households } \\
\text { income }\end{array}$} & MUP & 10532 & 4.198 & -0.560 & -0.962 \\
\hline & MUNP & 475905 & 0.024 & -0.448 & -0.924 \\
\hline & MRP & 10089 & 3.730 & -0.625 & -1.185 \\
\hline & MRNP & 178432 & 0.028 & -0.418 & -1.081 \\
\hline
\end{tabular}

Sources: Model results.

The GDP at a basic price increases in the first simulation. On the other hand, it decreases in the two other simulations. The growth of the GDP in the first scenario is justified by the increase in productivity of the sectors which are more intensive in unqualified labor, particularly in the agricultural sector $(+0,117 \%)$.

The government income drops significantly in the three scenarios. This is explained mainly by the fact that simulation 1 and 3 predict a reduction in income direct taxes and in the customs duties imposed by the government. These two are considered the major components of the public receipts.

For the first simulation, the public receipts generated by the improvement of the economic activity do not allow to compensate for the reduced value induced by the drop in income direct tax, and consequently, the public savings decreases approximately by $3,27 \%$.

For the second assumption, we should indicate that the income of the indirect taxes increases by $2,030 \%$. This is explained by the fact that the receipts generated by an increase of $20 \%$ in the tax of the industrial products and private services make it possible to compensate the reduction in these receipts due to the exemption of the agricultural and food products.

For simulation 3, the fall in public receipts is primarily due to the reduction in the transfers received by the government. Moreover, the incomes received from the customs duties decrease by 53,93\%. Consequently, public savings has strongly reduced by approximately $25,47 \%$.

The firms income increases by $0,03 \%$ in the SIM1 thanks to the increase in the domestic demand. On the other 
hand, this income decreases in the two other simulations.

The reduction in income direct tax makes it possible to have a positive effect on the disposable income of the households and more particularly on that of the poor. In fact, the disposable income of the urban poor households increases by $4,2 \%$ and that of the poor rural households by $3,7 \%$, which will generate a significant improvement of their purchasing power. In the same way, the income of the two other categories of households namely non-poor of both the urban and rural areas has slightly increased.

The two other policies presumed in the SIM2 and the SIM3 make it difficult to positively influence the disposable income of the households. On the contrary, they contribute to its reduction. It is also noticed that the increase in the indirect tax of the industrial products and the private services as well as the exemption of the agricultural and food products affect more negatively the poor income of households than that of the non-poor one.

\subsubsection{Wage Rate for Each Category of Workers}

Table 6. Variation of wage rate for each category of workers (by \%)

\begin{tabular}{lcccc}
\hline & Base & SIM1 & SIM2 & SIM3 \\
\hline unqualified workers (TNQ) & 1 & 0.021 & -0.550 & -0.911 \\
moderately qualified workers (TMQ) & 1 & 0.014 & -0.418 & -0.388 \\
highly qualified workers (THQ) & 1 & 0.010 & -0.376 & -0.267 \\
\hline
\end{tabular}

Sources: Model results.

The reduction in income direct tax in the first scenario allows the rise of the standard of wages for all the categories of workers. In fact, it is noticed that the wage rate of the unqualified workers $(+0,021 \%)$ increases twice as much as that of the highly qualified workers $(+0,010 \%)$. Moreover, in the agriculture and industry sectors, the labor demand augments especially for the unqualified workers.

The results of the SIM2 and SIM3 show that the evolution of the rate wage for all the categories of workers is negatively affected. Moreover, in these two simulations, the wage rate of the unqualified workers $(-0,55 \%$ and $-0,911 \%$ for SIM 2 and SIM3 respectively) is affected more seriously compared to the other categories of workers $(-0,376 \%$ and $-0,267$ for the highly qualified workers for instance).

In the third simulation, labor demand for the agricultural sector decreases by 3,939\%. However, it increases in the industrial sector by $1,327 \%$. Therefore, the policy supposed by this simulation contributes to reducing the price of the imported products. Within this context, the price of the agricultural commodity decreases by $12,767 \%$ and that of the food commodity by $5,201 \%$. Consequently, the resident agents substitute the local products by the imported ones. This reflects the increase in the imports of the agricultural products by $21,678 \%$ and the fall of production of this sector by $0,447 \%$. This situation encourages farmers to move towards the other sectors particularly the industrial one.

\subsubsection{Variation in the Household Consumption}

Table 4. Variation in the household consumption (by \%)

\begin{tabular}{lcccccc}
\hline SIMULATIONS & household categories & agricultural products & food products & industrial products & private services & public services \\
\hline \multirow{4}{*}{ SIM1 } & MUP & 2.899 & 4.571 & 4.611 & 4.391 & 4.392 \\
& MUNP & -0.023 & -0.023 & 0.014 & 0.004 & 0.005 \\
& MRP & 2.682 & 4.230 & 4.272 & 4.067 & 4.068 \\
& MRNP & -0.020 & -0.019 & 0.019 & 0.009 & 0.010 \\
SIM2 & MUP & -0.437 & 3.681 & -0.911 & -1.148 & -0.349 \\
& MUNP & -0.287 & 3.787 & -0.668 & -0.908 & -0.133 \\
& MRP & -0.473 & 3.815 & -0.977 & -1.223 & -0.389 \\
SIM3 & MRNP & -0.520 & 3.515 & -1.040 & -1.268 & -0.476 \\
& MUP & 1.858 & 1.154 & 0.070 & 0.174 & 0.063 \\
& MUNP & 1.722 & 1.000 & -0.047 & 0.059 & -0.048 \\
\hline
\end{tabular}

Sources: Model results. 
In the scenario of the income direct tax reduction for the poor households, the purchasing power of the latter increase, which enables them to increase their consumption. The results obtained for the SIM1 confirm this report. The urban and rural poor households' consumption increase for all the products. Therefore, the consumption of the agricultural commodities by the urban and rural poor households increases by $2,899 \%$ and 2,682\% respectively. For the other products, the rise of consumption exceeds $4 \%$.

For the non-poor households, their consumption decreases for both agricultural and food products. On the contrary, the consumption of the other products increases slightly.

The results of the policy combining the exemption from the indirect tax of the agricultural and food products as well as of public services, and the increase of this tax by $20 \%$ for the industrial products and the private services do not generally stimulate consumption. With the exception of the rise of food commodities consumption by all the households categories, the other products consumption drops.

The third scenario aiming at the exemption of the agricultural and food products from customs duties obviously leads to the fall of the prices of these products on the local market. Agricultural output decreases and the wages of the unqualified workers diminish. In this situation, although the income of the unqualified workers who constitute the majority of the poor households tends to decrease, their consumption increases. This is thanks to the fall in the prices of the products exempt from the customs duties (substitution effect is higher than the income effect).

The results analysis of the various illustrated simulations lead to the following remarks:

1 - Simulation 1 is the only one revealing an improvement of the economic growth.

2 - The three simulations lead to public receipts reduction.

3 - Only through simulation 1 , an increase in the disposable income of the households is perceived particularly that of the urban and rural poor.

4 - The tax raise of wages is achieved only in assumption 1 . Thus, an obvious improvement of this rate is noticed for the unqualified workers.

5 - The poor household consumption is increased in simulations 1 and 3.

As a result, The policy of the reduction in the direct taxes for the poor households has a more favorable effect compared to that of the two other supposed policies. It is noticeable that thanks to this policy, the income and consumption of the urban and rural poor households improve.

\section{Conclusion}

In the last years, Morocco launched a number of structuring projects, and started several social policies. The main objective is to revive the economy and ensure equity and social cohesion which can be achieved only by the eradication of poverty and the reduction of inequalities. Thus, to evaluate the economic and social impact of these policies, it is necessary to make studies based on general models taking into account several dimensions. This paper studies the impact of a number of fiscal policies on the evolution of disposable income and the level of the household consumption particularly for the urban and rural poor households. The supposed simulations are made within the framework of a CGEM. The adopted approach disagregates the agent households into four categories: according to levels of income (poor or non-poor), and to place of living (urban or rural). In spite of the limits of this approach compared to the approach of micro simulation, it should be noted that our model was gauged by using the most recent data available, a social accounting matrix of Morocco of 2013 which was published by the HCP in June 2016 and the ENNVM of 2007.

Three simulations of fiscal policies were implemented. The comparison and analysis of the results obtained are made paying close attention to the disposable income of the households particularly the urban and rural poor as well as their consumption. The results show that the simulation which consists of $50 \%$ reduction in direct tax on the income of the poor urban households in addition to exempting from this tax the poor rural households is more favorable to the increase in the disposable income and to the improvement of their consumption. Certainly, these improvements will have a positive impact on the reduction of poverty and inequalities in Morocco. A more detailed analysis will be carried out by building a CGEM- microsimulation, and by using the most recent data in order to refine the results obtained in this work.

\section{References}

Abdelkhalek, T. (2009). Cadre stratégique national de réduction de la pauvreté au Maroc: A propos du concept de pauvreté et analyse de la situation. Rapport de consultation pour le PNUD et pour le Ministère du 
développement social, de la famille et de la solidarité.

Abdelkhalek, T., Boccanfuso, D., \& Savard, L. (2009). Politiques économiques, pauvreté et inégalités au Maroc: Analyses en équilibre général micro simulé. Mondes en Développement, 4(148), 99-118. https://doi.org/10.3917/med.148.0099

Adelman, I., \& Robinson, S. (1978). Income Distribution Policy: A Computable General Equilibrium Model of South Korea. Stanford: Stanford University Press.

Aredo, D. S., Fekadu, B., \& Kebede, S. W. (2012). Trade Liberalization and Poverty: A Macro-Micro Analysis in Ethiopia. MPIA Working Paper No. 2012-04

Armington, P. S. (1969). A Theory of Demand for Products Distinguished by Place of Production, I.M.F. Staff Papers, 16, 159-176. https://doi.org/10.2307/3866403

Bourguignon, F., \& Morisson, C. (1991). Poverty and Income Distribution During Adjustment: Issues and Evidence from the OECD Project. World Development, 19(11), 1485-1508. https://doi.org/10.1016/0305-750X(91)90002-Y

Bourguignon, F., Bussolo, M., \& Da Silva, L, P. (2008). The impact of macroeconomic policies on poverty and income distribution: Macro-micro evaluation techniques and tools. Copublication of The World Bank and Palgrave Macmillan

Bourguignon, F., De Melo, J., \& Suwa, A. (1991). Modelling the effects of adjustment programs on income distribution. World Development, 19(11), 1527-1544. https://doi.org/10.1016/0305-750X(91)90004-2

Bourguignon, F., Pereira da silva, L., \& Stern, N. (2002). Evaluating the Poverty Impact of Economic Policies: Some Analytical Challenges. Retrieved from http://www.undp.org/rblac/documents/poverty/Bourguignon-PovandMacro.pdf

Chen, S., \& Ravallion, M. (2003). Measuring Pro-Poor Growth, World Bank, Policy Research. Working Paper 2666.

Chia, N. C., Wahba, S., \& Whalley, J. (1994). Poverty-Reduction Targeting Programs: A General Equilibrium $\begin{array}{lllll}\text { Approach. Journal of African } & \text { Economies, } & 3(2), & 309-338 .\end{array}$ https://doi.org/10.1093/oxfordjournals.jae.a036807

Cockburn, J. (2001). Trade liberalization and poverty in Nepal: A computable general equilibrium micro simulation analysis. CREFA working paper (01-18). Retrieved from http://www.crefa.ecn.ulaval.ca/cahier/0118.pdf

De Janvry, A., Sadoulet, E., \& Fargeix, A. (1991). Adjustment and Equity in Ecuador. OECD Development Center, Paris.

Decaluwé, B., Dumont, J. C., \& Savard, L. (1999). Measuring Poverty and Inequality in a Computable General Equilibrium Model. Working Paper 99-20 CREFA, University of Laval.

Decaluwé, B., Lemelin, A., Robichaud, V., \& Maisonnave, H. (2013). The PEP standard single-country static CGE model. Partnership Economic Policy.

Decaluwé, B., Patry, A., \& Savard, L. (1998). Income Distribution, Poverty Measures and Trade Shocks: A Computable General Equilibrium Model of a Archetype Developing Country. Working Paper 98-14 CREFA, University of Laval.

Dervis, K, De Melo, J., \& Robinson, S. (1982). General Equilibrium Models for Development Policy. London: Cambridge University Press.

Dorosh, P. A., \& Sahn, D. E (2000). A General Equilibrium Analysis of the Effect of Macroeconomic Adjustment on Poverty in Africa. Journal of Policy Modelling, 22(6), 753-76. https://doi.org/10.1016/S0161-8938(98)00016-7

Haut Commissariat au Plan. (2009). Simulations de l'impact de politiques économiques sur la pauvreté et les inégalités: Modèle d'équilibre général calculable en Microsimulation Pour l'économie marocaine. Rabat.

Hertel, T., \& Reimer, J. (2005). Predicting the Poverty Impacts of Trade Reform. Journal of International Trade \& Economic Development, 14(4), 377-405. https://doi.org/10.1080/09638190500372404

Lofgren, H. (1999). Trade reform and the poor in Morocco: A rural-urbain general equilibrium analysis of reduced proctection. TMD discussion paper $\mathrm{n}^{\circ} 38$ 
Morrisson, C. (1991). Adjustment incomes and Poverty in Morocco. World Development, 19(11), $1633-1651$. https://doi.org/10.1016/0305-750X(91)90010-F

Thorbecke, E. (1991). Adjustment growth and income distribution in Indonesia and Equity in Indonesia. World Development, 19(11), 1595-1614. https://doi.org/10.1016/0305-750X(91)90008-6

Xinshen, D., Doukkali, R., \& Yu, B. (2008). Policy options and their potential effects on Moroccan small farmers and the poor facing increased World food prices: A General Equilibrium Model Analysis. IFPRI discussion paper 00813.

\section{Copyrights}

Copyright for this article is retained by the author(s), with first publication rights granted to the journal.

This is an open-access article distributed under the terms and conditions of the Creative Commons Attribution license (http://creativecommons.org/licenses/by/4.0/). 